\title{
Hydrogenivirga caldilitoris gen. nov., sp. nov., a novel extremely thermophilic, hydrogen- and sulfur-oxidizing bacterium from a coastal hydrothermal field
}

Correspondence

Satoshi Nakagawa

nakasato@kais.kyoto-u.ac.jp

\author{
Satoshi Nakagawa, ${ }^{1}$ Sachiko Nakamura, ${ }^{1}$ Fumio Inagaki, ${ }^{2}$ Ken Takai, ${ }^{2}$ \\ Nobuaki Shirai ${ }^{3}$ and Yoshihiko Sako ${ }^{1}$ \\ ${ }^{1}$ Laboratory of Marine Microbiology, Graduate School of Agriculture, Kyoto University, \\ Kyoto 606-8502, Japan \\ ${ }^{2}$ Subground Animalcule Retrieval (SUGAR) Project, Frontier Research System for \\ Extremophiles, Japan Agency of Marine-Earth Science and Technology 2-15 \\ Natsushima-cho, Yokosuka 237-0061, Japan \\ ${ }^{3}$ Industrial Research Center of Shiga Prefecture, Kamitoyama 232, Ritto 520-3004, Japan
}

The family Aquificaceae comprises four genera, Aquifex, Hydrogenobacter, Thermocrinis and Hydrogenobaculum (Reysenbach, 2001). Members of the family Aquificaceae, growing optimally at $65-85^{\circ} \mathrm{C}$, are obligately or facultatively chemolithoautotrophic hydrogen/sulfur oxidizers except for an obligate heterotroph of Hydrogenobacter subterraneus strain $\mathrm{HGP}^{\mathrm{T}}$ (Takai et al., 2001). Although all the isolates of the genera Hydrogenobacter, Thermocrinis and Hydrogenobaculum have been obtained from various

\footnotetext{
Published online ahead of print on 30 April 2004 as DOI 10.1099/ ijs.0.03031-0.

The GenBank/EMBL/DDBJ accession number for the 16S rRNA gene sequence of strain IBSK3 ${ }^{\top}$ is $A B 120294$.

A phase-contrast micrograph of Hydrogenivirga caldilitoris strain IBSK ${ }^{\top}$ cells showing filamentous morphology and graphs showing the effects of temperature, $\mathrm{pH}, \mathrm{NaCl}$ concentration and $\mathrm{O}_{2}$ concentration in the gas phase on the growth of $H$. caldilitoris strain IBSK ${ }^{\top}$ are available as supplementary material in IJSEM Online.
}

terrestrial geothermal systems (Kawasumi et al., 1984; Kryukov et al., 1984; Kristjansson et al., 1985; Huber et al., 1992, 1998; Shima \& Suzuki, 1993; Skirnisdottir et al., 2001; Takai et al., 2001; Eder \& Huber, 2002), members of the genus Aquifex have been isolated from marine hydrothermal systems (Huber et al., 1992; Deckert et al., 1998; Van Dover et al., 2001; Eder \& Huber, 2002). All species of the family Aquificaceae are capable of utilizing molecular oxygen as an electron acceptor, and Hydrogenobacter thermophilus strain TK-6 ${ }^{\mathrm{T}}$ and Aquifex pyrophilus strain $\mathrm{Kol} 5 \mathrm{a}^{\mathrm{T}}$ can grow under anaerobic conditions with nitrate as an electron acceptor (Huber et al., 1992; Suzuki et al., 2001). However, no member of the family Aquificaceae that utilizes thiosulfate as an electron acceptor has been reported, while $A$. pyrophilus strain $\mathrm{Kol}_{5} \mathrm{a}^{\mathrm{T}}$ and Thermocrinis ruber strain OC $1 / 4^{\mathrm{T}}$ are able to use thiosulfate as an electron donor. Thiosulfate might play an important role in energy metabolism in marine hydrothermal microbial ecosystems (e.g. Stetter, 1988; Sako et al., 1996; L'Haridon 
et al., 1998; Nakagawa et al., 2003b). In this study, we sought to cultivate hydrogen-oxidizing thermophiles from a coastal hot spring using thiosulfate as an electron acceptor.

Samples used in this study were collected from a coastal hot spring in Ibusuki, Kagoshima Prefecture, Japan. Sandy sediments with hot fluids were collected at the beach (original temperature around $70^{\circ} \mathrm{C}$ ) and immediately brought to our laboratory without redox and temperature controls. The samples were used to inoculate a series of media, including HT medium. HT medium contained $1 \mathrm{~g}$ $\mathrm{Na}_{2} \mathrm{~S}_{2} \mathrm{O}_{3} \cdot 5 \mathrm{H}_{2} \mathrm{O}, 1 \mathrm{~g} \mathrm{NaHCO}$ and $10 \mathrm{ml}$ vitamin solution (Balch et al., 1979) per litre of DMJ synthetic sea water (Nakagawa et al., 2003a). To prepare HT medium, $1 \mathrm{~g}$ $\mathrm{Na}_{2} \mathrm{~S}_{2} \mathrm{O}_{3} \cdot 5 \mathrm{H}_{2} \mathrm{O}$ and all the components of DMJ synthetic sea water were dissolved in 1 litre distilled deionized water, and the $\mathrm{pH}$ was adjusted to around $7 \cdot 0$ with $\mathrm{NaOH}$ at room temperature prior to autoclaving. After autoclaving, filtersterilized $\mathrm{NaHCO}_{3}$ solution and vitamin solution were added aseptically. Then, the tube was tightly sealed with a butyl-rubber stopper under a gas phase of $80 \% \mathrm{H}_{2} / 20 \%$ $\mathrm{CO}_{2}(300 \mathrm{kPa})$.

The enrichment was performed in test tubes (Pyrex; $180 \mathrm{~mm} \times 18 \mathrm{~mm}$ ) containing $5 \mathrm{ml}$ of the medium with $80 \% \mathrm{H}_{2} / 20 \% \mathrm{CO}_{2}(300 \mathrm{kPa})$ that were tightly sealed with butyl-rubber stoppers, and the cultures were incubated at $75^{\circ} \mathrm{C}$. The tubes of HT medium became turbid after 3 days incubation at $75^{\circ} \mathrm{C}$. The enrichment cultures grown at $75^{\circ} \mathrm{C}$ contained motile short rods and filaments. To obtain a pure culture, a dilution-to-extinction method was employed and repeated at least five times (Baross, 1995). The first pure culture was designated strain IBSK $3^{\mathrm{T}}(=\mathrm{JCM}$ $12173^{\mathrm{T}}=$ ATCC BAA- $821^{\mathrm{T}}$ ) and investigated in detail. The purity was confirmed routinely by microscopic examination and by repeated partial sequencing of the $16 \mathrm{~S}$ rRNA gene using several PCR primers.

Cells were routinely observed with a differential interference microscope (UFX; Nikon). Negative staining of cells for electron microscopy was achieved with $2 \%(\mathrm{w} / \mathrm{v})$ phosphotungstic acid as described previously (Sako et al., 2003). The cells were Gram-negative rods with a mean length of $1 \cdot 2-3 \cdot 0 \mu \mathrm{m}$ and a width of approximately $0 \cdot 3-0 \cdot 4 \mu \mathrm{m}$. The cells appeared to be motile by observation under a light microscope and to have a single polar flagellum as observed by electron microscopy. Electron micrographs of thin sections showed that the isolate had an envelope consisting of a wavy outer membrane and a cytoplasmic membrane with a simple outline (Fig. 1). Cells occurred singly, in pairs and in aggregates of up to about 100 individuals; no sporulation was apparent in the laboratory cultures. In the late-exponential phase of growth, some filamentous cells (up to $50 \mu \mathrm{m}$ long) were observed (see Fig. A, available as supplementary material in IJSEM Online). Under the UV microscope at $420 \mathrm{~nm}$, cells did not exhibit the bluishgreen fluorescence that was reported for A. pyrophilus strain $\mathrm{Kol5a}^{\mathrm{T}}$ (Huber et al., 1992).

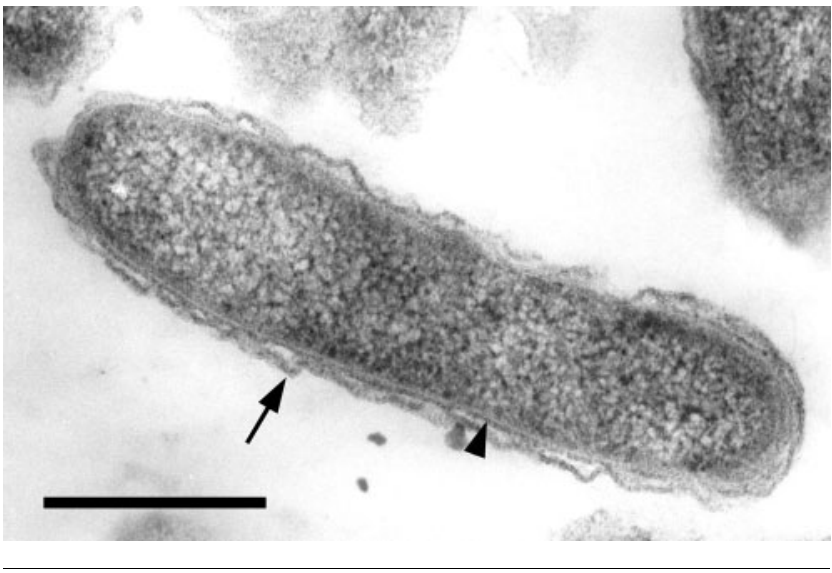

Fig. 1. Electron micrograph of a thin section of Hydrogenivirga caldilitoris strain $\mathrm{IBSK}^{\top}$ cells showing cytoplasmic membrane (arrowhead) and outer membrane (arrow, left). Bar, $0.5 \mu \mathrm{m}$.

Although the novel isolate was purified and cultivated in HT medium over 2 months (subcultured once a week), the growth gradually became inconsistent. The addition of nitrate was found to stimulate the growth of the isolate; therefore, HT medium supplemented with $0 \cdot 1 \%(\mathrm{w} / \mathrm{v})$ $\mathrm{NaNO}_{3}$ (designated HTN medium) was used in the following experiments unless noted otherwise.

Growth of the novel isolate was determined by direct cell counts, after staining with 4',6-diamidino-2-phenylindole (DAPI) (Porter \& Feig, 1980), using a Nikon Eclipse E800 microscope equipped with a colour chilled 3 CCD camera system (C5810; Hamamatsu Photonics, Hamamatsu, Japan). To determine temperature, $\mathrm{pH}$ and $\mathrm{NaCl}$ ranges for growth, duplicate cultures were grown in $100 \mathrm{ml}$ glass bottles (Schott) containing $20 \mathrm{ml}$ medium in an air-batch rotary shaker (RGS-32.TT; Sanki Seiki, Osaka, Japan) and were shaken at 100 r.p.m. in all cases. The isolate grew over the temperature range of about $55-77 \cdot 5^{\circ} \mathrm{C}$, showing optimum growth at $75^{\circ} \mathrm{C}$. The generation time and maximum cell yield at $75^{\circ} \mathrm{C}, \mathrm{pH} 7 \cdot 0$, were about $2 \mathrm{~h}$ and approximately $2 \cdot 0 \times 10^{8} \mathrm{cells} \mathrm{m}^{-1}$, respectively. No growth was observed at $80^{\circ} \mathrm{C}$ or $50^{\circ} \mathrm{C}$ (see Fig. Ba, available as supplementary material in IJSEM Online). Effects of $\mathrm{pH}$ and $\mathrm{NaCl}$ concentration on the growth of the isolate were determined at $75^{\circ} \mathrm{C}$. When the $\mathrm{pH}$ optimum was examined, $\mathrm{pH}$ of the medium was readjusted immediately before inoculation with $\mathrm{H}_{2} \mathrm{SO}_{4}$ or $\mathrm{NaOH}$ by using a compact $\mathrm{pH}$ meter (Horiba B-212) at $75^{\circ} \mathrm{C}$. The $\mathrm{pH}$ was found to be stable during the cultivation period. Growth of the novel isolate occurred between $\mathrm{pH} 5 \cdot 5$ and $8 \cdot 3$, with optimum growth at approximately $\mathrm{pH} 6 \cdot 5-7 \cdot 0$. No growth was detected at $\mathrm{pH} 4.3$ or $\mathrm{pH} 9 \cdot 4$ (see Fig. Bb, available as supplementary material in IJSEM Online). $\mathrm{NaCl}$ requirements were determined with varying concentrations of $\mathrm{NaCl}$ in DMJ synthetic sea water from 0 to $6 \%(\mathrm{w} / \mathrm{v})$. The isolate absolutely required $\mathrm{NaCl}$ for growth, and grew in the concentration range of about $0 \cdot 5$ to $4 \cdot 0 \% \mathrm{NaCl}$, with 
optimum growth at around $2 \cdot 0 \% \mathrm{NaCl}$. No growth was observed at 0 or $5.0 \% \mathrm{NaCl}$ (see Fig. Bc, available as supplementary material in IJSEM Online). The $\mathrm{pH}$ and $\mathrm{NaCl}$ ranges for the growth of the novel isolate were generally similar to those of $A$. pyrophilus strain $\mathrm{Kol}_{5} \mathrm{a}^{\mathrm{T}}$ (Huber et al., 1992), but the temperature range was shifted to significantly lower temperatures.

$\mathrm{O}_{2}$ tolerance and requirement were determined by injecting defined volumes of $\mathrm{O}_{2}$ into culture bottles of HTN medium without $\mathrm{Na}_{2} \mathrm{~S}_{2} \mathrm{O}_{3} \cdot 5 \mathrm{H}_{2} \mathrm{O}$ and $\mathrm{NaNO}_{3}$ as described previously (Nakagawa et al., 2003a). The final concentration of $\mathrm{O}_{2}$ from 0 to $15 \%(\mathrm{v} / \mathrm{v})$ was tested. A limited quantity of $\mathrm{O}_{2}(0 \cdot 4-7 \cdot 7 \%$; optimum $2 \%$; v/v) supported growth (see Fig. Bd, available as supplementary material in IJSEM Online). Microaerobic growth with the optimal $\mathrm{O}_{2}$ concentration produced a lower growth rate and yield than anaerobic growth in HTN medium.

The following analytical procedures were used for testing the change of inorganic substrates during bacterial growth in HTN medium. Gas composition was measured by using the gas chromatograph Micro GC CP2002 (GL Sciences). Anion samples were analysed by ion chromatography using a Shim-pack IC column (Shimadzu). The diazotization method was employed to determine the concentration of nitrate/nitrite (Matsunaga \& Nishimura, 1969) in addition to ion chromatography, and Nessler's reagent was employed to measure the ammonia concentration in the medium (Allen et al., 1974). The concentration of $\mathrm{N}_{2} \mathrm{O}$ in the gas phase was increased with decreasing concentration of nitrate during growth. The consumption of thiosulfate during the bacterial growth was not detected (Fig. 2). The accumulation of potential end products such as nitrite, $\mathrm{N}_{2}$, $\mathrm{H}_{2} \mathrm{~S}$ and ammonium ions was not detected.

In an attempt to examine the electron acceptors that could

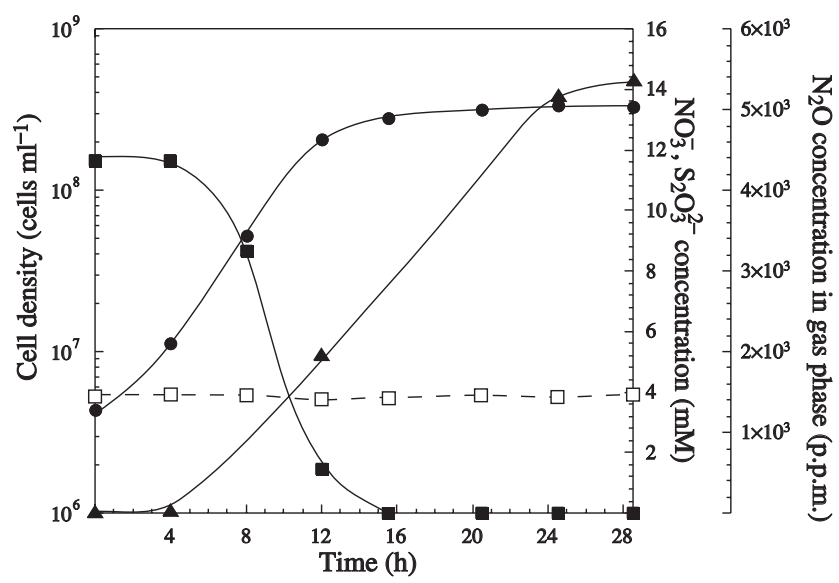

Fig. 2. Growth and production of $\mathrm{N}_{2} \mathrm{O}$ from nitrate during the growth of Hydrogenivirga caldilitoris strain IBSK3 ${ }^{\top}$. Growth curve (0), production of $\mathrm{N}_{2} \mathrm{O}(\boldsymbol{\Delta})$, and the concentrations of nitrate $(\boldsymbol{\square})$ and thiosulfate $(\square)$ are shown. support growth, $0.1 \%(\mathrm{w} / \mathrm{v}) \mathrm{NaNO}_{3}, \mathrm{Na}_{2} \mathrm{~S}_{2} \mathrm{O}_{3} .5 \mathrm{H}_{2} \mathrm{O}$, $\mathrm{NaNO}_{2}$ and $\mathrm{Na}_{2} \mathrm{SO}_{3}, 3 \%(\mathrm{w} / \mathrm{v}) \mathrm{S}^{0}$ and $100 \mathrm{mM}$ ferrihydrite were tested under the gas phase of $80 \% \mathrm{H}_{2} / 20 \% \mathrm{CO}_{2}$ $(300 \mathrm{kPa})$. Only $\mathrm{NaNO}_{3}$ could serve as a sole electron acceptor for growth.

The nitrogen source for growth $\left(\mathrm{NH}_{4} \mathrm{Cl}, \mathrm{NaNO}_{2}, \mathrm{~N}_{2}\right.$ or $\mathrm{NaNO}_{3}$ ) was also examined with $\mathrm{HTN}$ medium lacking all nitrogen source under the gas phase of $80 \% \mathrm{H}_{2} / 18 \%$ $\mathrm{CO}_{2} / 2 \% \mathrm{O}_{2}(300 \mathrm{kPa})$. Strain IBSK3 ${ }^{\mathrm{T}}$ utilized ammonium or nitrate as a nitrogen source but could not utilize molecular nitrogen or nitrite.

To test alternative energy sources, $0 \cdot 1 \% \quad(\mathrm{w} / \mathrm{v})$ $\mathrm{Na}_{2} \mathrm{~S}_{2} \mathrm{O}_{3} .5 \mathrm{H}_{2} \mathrm{O}, 3 \%(\mathrm{w} / \mathrm{v}) \quad \mathrm{S}^{0}$ and organic substrates (described below) were tested in DMJ synthetic sea water supplemented with $0 \cdot 1 \%(\mathrm{w} / \mathrm{v}) \mathrm{NaNO}_{3}$ and $\mathrm{NaHCO}_{3}$ under a gas phase of $80 \% \mathrm{~N}_{2} / 20 \% \mathrm{CO}_{2}(300 \mathrm{kPa})$. This test was also conducted in DMJ synthetic sea water supplemented with $0 \cdot 1 \%(\mathrm{w} / \mathrm{v}) \mathrm{NaHCO}_{3}$ under a gas phase of $80 \% \mathrm{~N}_{2} / 18 \% \mathrm{CO}_{2} / 2 \% \mathrm{O}_{2}(300 \mathrm{kPa})$. Strain IBSK $3^{\mathrm{T}}$ could utilize only $\mathrm{S}^{0}$ as an alternative electron donor under the anaerobic condition with nitrate or the microaerobic condition. To determine the end product of $S^{0}$ oxidation, strain IBSK $^{\mathrm{T}}$ was grown in medium in which all the sulfate salts of DMJ synthetic sea water had been replaced with the chloride salts (Takai et al., 2002). In the lateexponential phase of growth on $\mathrm{S}^{0}$ and either $\mathrm{O}_{2}$ or $\mathrm{NO}_{3}^{-}$, the production of $\mathrm{SO}_{4}^{2-}$ was observed by using capillary electrophoresis P/ACE MDQ (Beckman Coulter) (Soga \& Ross, 1999). The accumulation of potential end products such as $\mathrm{SO}_{3}^{2-}$ was not detected.

In an attempt to examine the ability of strain $\operatorname{IBSK}^{\mathrm{T}}$ to utilize organic compounds as energy and carbon sources, experiments were conducted using HTN medium in the absence of $\mathrm{NaHCO}_{3}$ containing various organic carbon sources. Each of the following substrates was added at concentrations of 0.01 and $0.1 \%(\mathrm{w} / \mathrm{v})$ : L-cystine, Lphenylalanine, L-proline, Casamino acids, $(+)$-D-glucose, lactose, maltose, chitin, starch, cellulose, formate, formaldehyde, formamide, acetate, citrate, pyruvate, propionate, 2-propanol, methanol, tryptone peptone (Difco) and yeast extract (Difco). Two gas phases $\left(100 \% \mathrm{H}_{2}\right.$ or $80 \% \mathrm{~N}_{2} / 20 \%$ $\left.\mathrm{CO}_{2} ; 300 \mathrm{kPa}\right)$ were used. These tests were conducted in duplicate. Strain IBSK $^{\mathrm{T}}$ was unable to use any organic compounds as either energy or carbon sources. These results indicated that the novel isolate was a strict chemolithoautotroph.

The cellular fatty acid composition of strain IBSK $^{\mathrm{T}}$ was analysed using cells grown in $\mathrm{HTN}$ medium at $75^{\circ} \mathrm{C}$ in the late-exponential phase of growth. Lyophilized cells (100 mg) were placed in a Teflon-lined, screw-capped tube containing $3 \mathrm{ml}$ of anhydrous methanolic $\mathrm{HCl}$ and heated at $100{ }^{\circ} \mathrm{C}$ for $3 \mathrm{~h}$. The extraction and analysis of fatty acid methyl esters have been described previously (Takai et al., 2003). The major cellular fatty acids of strain $\mathrm{IBSK}^{\mathrm{T}}$ were $\mathrm{C}_{20: 1}(41 \cdot 8 \%), \mathrm{C}_{18: 0}(34 \cdot 4 \%), \mathrm{C}_{20: 0}(9 \cdot 0 \%), \mathrm{C}_{22: 1}(4 \cdot 4 \%)$ 


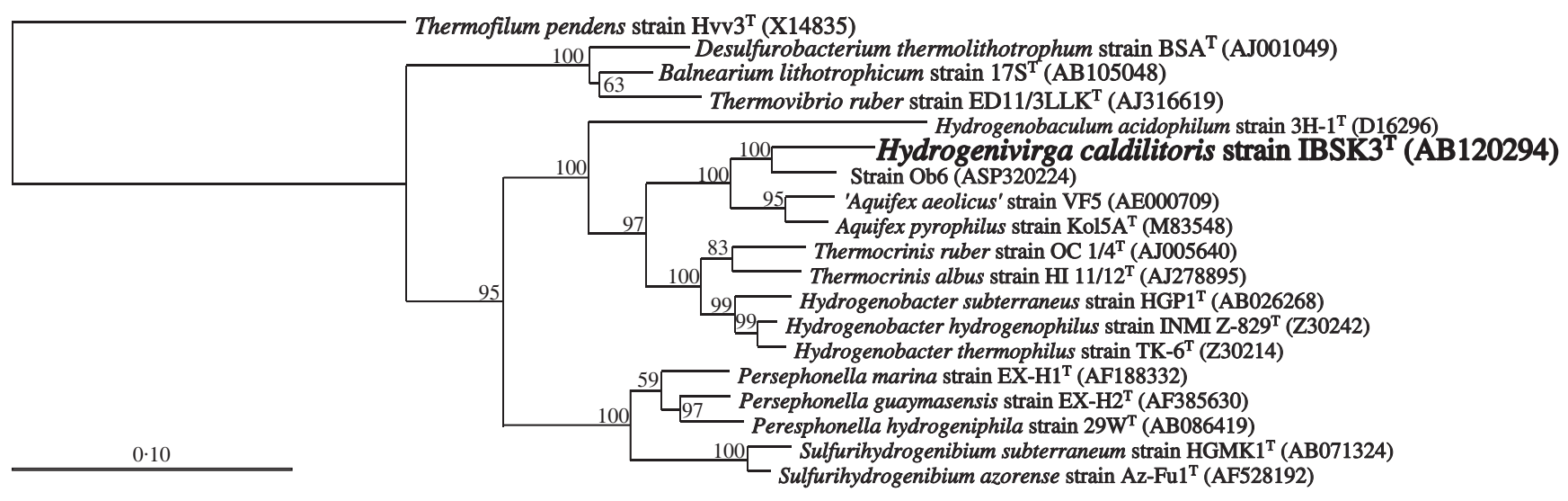

Fig. 3. Phylogenetic tree of representative members and of thermophilic hydrogen-oxidizing bacteria, inferred from $16 \mathrm{~S}$ rRNA gene sequences by the neighbour-joining method using 1182 homologous sequence positions for each organism. The numbers are the bootstrap values for the branches (based on 100 replicates). This topology was confirmed by maximumparsimony and maximum-likelihood methods. Bar, 10 substitutions per 100 nucleotides. The GenBank/EMBL/DDBJ database accession numbers are shown in parentheses.

and $\mathrm{C}_{18: 1}(3 \cdot 8 \%)$. The presence of $\mathrm{C}_{20: 1}$ and $\mathrm{C}_{18: 0}$ as the major components is a common feature with the members of the family Aquificaceae (Jahnke et al., 2001); however, the novel isolate can be distinguished by the presence of relatively high amounts of $\mathrm{C}_{18: 0}, \mathrm{C}_{20: 0}$ and $\mathrm{C}_{22: 1}$.

Genomic DNA was prepared as described by Lauerer et al. (1986). The $\mathrm{G}+\mathrm{C}$ content (mol\%) of the genomic DNA was determined by direct analysis of deoxyribonucleotides using HPLC with a DNA-GC kit (Yamasa Shouyu, Chiba, Japan) after digestion of the DNA with nuclease P1 (Tamaoka \& Komagata, 1984). The $\mathrm{G}+\mathrm{C}$ content of the genomic DNA of strain IBSK $3^{\mathrm{T}}$ was found to be $49 \cdot 2 \mathrm{~mol} \%$.

The 16S rRNA gene of strain IBSK $^{\mathrm{T}}$ was amplified by PCR using primers Eubac 27F and 1492R (DeLong, 1992). The sequence of the $1.5 \mathrm{~kb}$ PCR product was determined directly in both strands using the dideoxynucleotide chaintermination method with a DNA sequencer (ABI 373A; Applied Biosystems). In order to determine the phylogenetic position of strain $\mathrm{IBSK}^{\mathrm{T}}$, the almost-complete sequence (1492 bp) was aligned with a subset of 16S rRNA gene sequences obtained from the DDBJ by using the FastAligner utility of the ARB software (http://www.arb-home.de). The resulting alignment was verified against known secondary regions, and only unambiguously aligned nucleotide positions (1182 bases) were used for phylogenetic analyses with PAUP $^{*} 4.0$ beta 10 (Swofford, 2000). A phylogenetic tree was inferred by using neighbour-joining analysis (Saitou \& Nei, 1987) with the Jukes-Cantor correction (Jukes \& Cantor, 1969). Bootstrap analysis was used for 100 trial replications to provide confidence estimates for the phylogenetic tree topologies. Although the phylogenetic tree demonstrated that strain IBSK $3^{\mathrm{T}}$ was a member of the family Aquificaceae, the isolate was on a distinct branch deeply separated from a cluster of the branch of Aquifex species (Fig. 3). Alternative methods of phylogenetic analysis, maximum-parsimony and maximum-likelihood, produced identical results. 16S rRNA gene sequence similarity values between strain IBSK $3^{\mathrm{T}}$ and $A$. pyrophilus strain Kol5a $\mathrm{a}^{\mathrm{T}}$ and 'Aquifex aeolicus' strain VF5 were $91 \cdot 3 \%$ and $90.9 \%$, respectively. The $16 \mathrm{~S}$ rRNA gene sequence of the novel isolate was found to be $94 \cdot 6 \%$ similar to that of a hydrogen-oxidizing thermophile designated strain Ob6, a member of the family Aquificaceae isolated from an African coastal hot spring (Eder \& Huber, 2002); however, the physiological properties of strain Ob6 have not been reported.

The phylogenetic analysis based on the 16S rRNA gene sequence indicated that strain IBSK $3^{\mathrm{T}}$ was distantly related to previously described members of the family Aquificaceae. Only two marine Aquifex species, A. pyrophilus strain $\mathrm{Kol} 5 \mathrm{a}^{\mathrm{T}}$ (Huber et al., 1992) and 'A. aeolicus' strain VF5 (Deckert et al., 1998), have been reported. Based on molecular and physiological properties, strain IBSK $^{\mathrm{T}}$ can be clearly distinguished from these organisms (Table 1). Although strain IBSK $3^{\mathrm{T}}$ is able to grow under both anaerobic and microaerobic conditions, as is A. pyrophilus strain $\mathrm{Kol}_{5} \mathrm{a}^{\mathrm{T}}$, it grows at a significantly lower temperature range and has a lower optimum temperature for growth (Table 1). The level of 16S rRNA gene sequence similarity between strain IBSK $3^{\mathrm{T}}$ and any recognized species within the family Aquificaceae was less than $92 \%$. The similarity is within the common index of $16 \mathrm{~S}$ rRNA gene sequence similarity for genus-level differentiation (90-96\%) (Gillis et al., 2001).

On the basis of the properties of strain IBSK $3^{\mathrm{T}}$, we propose a new genus, Hydrogenivirga gen. nov., with type species Hydrogenivirga caldilitoris sp. nov. 
Table 1. Comparison of properties of Hydrogenivirga caldilitoris gen. nov., sp. nov. and related species

Taxa: 1, Hydrogenivirga caldilitoris strain $\operatorname{IBSK}^{\mathrm{T}}$ (data from this study); 2, Aquifex pyrophilus strain $\mathrm{Kol}^{\mathrm{T}} \mathrm{a}^{\mathrm{T}}$ (Huber et al., 1992); 3, Hydrogenobacter thermophilus strain TK-6 ${ }^{\mathrm{T}}$ (Kawasumi et al., 1984; Suzuki et al., 2001; Eder \& Huber, 2002); 4, Thermocrinis ruber strain OC $1 / 4^{\mathrm{T}}$ (Huber et al., 1998). ND, No data, +, motile; -, non-motile.

\begin{tabular}{|c|c|c|c|c|}
\hline Character & 1 & 2 & 3 & 4 \\
\hline Temperature range $\left({ }^{\circ} \mathrm{C}\right)$ & $55 \cdot 0-77 \cdot 5$ & $67-95$ & $50-78$ & $44-89$ \\
\hline Temperature optimum $\left({ }^{\circ} \mathrm{C}\right)$ & 75 & 85 & $70-75$ & 80 \\
\hline $\mathrm{NaCl}$ range $(\%, \mathrm{w} / \mathrm{v})$ & $0 \cdot 5-4 \cdot 0$ & $1 \cdot 0-5 \cdot 0$ & $\mathrm{ND}$ & $0-0 \cdot 4$ \\
\hline $\mathrm{NaCl}$ optimum $(\%, w / v)$ & $2 \cdot 0$ & $3 \cdot 0$ & $\mathrm{ND}$ & ND \\
\hline Electron donor & $\mathrm{H}_{2}, \mathrm{~S}^{0}$ & $\mathrm{H}_{2}, \mathrm{~S}_{2} \mathrm{O}_{3}^{2-}, \mathrm{S}^{0}$ & $\mathrm{H}_{2}$, formate, formamide & $\begin{array}{l}\mathrm{H}_{2}, \mathrm{~S}_{2} \mathrm{O}_{3}^{2-}, \mathrm{S}^{0} \text {, } \\
\text { formate, formamide }\end{array}$ \\
\hline Electron acceptor & $\mathrm{NO}_{3}^{-}, \mathrm{O}_{2}$ & $\mathrm{NO}_{3}^{-}, \mathrm{O}_{2}$ & $\mathrm{O}_{2}, \mathrm{NO}_{3}^{-}$ & $\mathrm{O}_{2}, \mathrm{~S}^{0}$ \\
\hline
\end{tabular}

*Adaptation up to $6 \%$ was observed.

\section{Description of Hydrogenivirga gen. nov.}

Hydrogenivirga (Hy.dro.ge.ni.vir'ga. N.L. neut. n. hydrogenum hydrogen; L. n. virga rod; N.L. fem. n. Hydrogenivirga hydrogen rod).

Cells occur singly, in pairs, in aggregates or as filaments. Motile. Gram-negative. Anaerobic to microaerobic. Thermophilic. Strictly chemolithoautotrophic. Able to utilize molecular hydrogen or elemental sulfur as electron donor and oxygen or nitrate as electron acceptor. $\mathrm{NaCl}$ is absolutely required for growth. $\mathrm{G}+\mathrm{C}$ content of genomic DNA is about 50 mol\%. Major cellular fatty acids are $\mathrm{C}_{20: 1}, \mathrm{C}_{18: 0}$ and $\mathrm{C}_{20: 0}$. On the basis of $16 \mathrm{~S}$ rRNA gene sequence analysis, the genus Hydrogenivirga is distantly related to the genus Aquifex. Members of the genus Hydrogenivirga occur at coastal hydrothermal fields.

The type species is Hydrogenivirga caldilitoris.

\section{Description of Hydrogenivirga caldilitoris sp. nov.}

Hydrogenivirga caldilitoris (cal.di.lit'o.ris. L. adj. caldus hot; L. n. litus-oris beach; N.L. gen. n. caldilitoris of a hot beach).

Cells are motile, with a mean length of $2 \cdot 0 \mu \mathrm{m}$ and width of approximately $0.3 \mu \mathrm{m}$. Some cells occur as filaments in the late-exponential phase of growth. The temperature range for growth is $55-77 \cdot 5^{\circ} \mathrm{C}$ (optimum $75^{\circ} \mathrm{C}$ ). The $\mathrm{pH}$ range for growth is $5 \cdot 5-8 \cdot 3$ (optimum $6 \cdot 5-7 \cdot 0$ ). $\mathrm{NaCl}$ in the concentration range of $5-40 \mathrm{~g} \mathrm{l}^{-1}$ is an absolute growth requirement, optimum growth occurs at $20 \mathrm{~g} \mathrm{l}^{-1}$. Strictly chemolithoautotrophic: growth occurs with molecular hydrogen or elemental sulfur as electron donor and with oxygen or nitrate as electron acceptor. Nitrate is reduced to $\mathrm{N}_{2} \mathrm{O}$. The major cellular fatty acids are $\mathrm{C}_{20: 1}$ $(41 \cdot 8 \%), \mathrm{C}_{18: 0}(34 \cdot 4 \%), \mathrm{C}_{20: 0}(9 \cdot 0 \%), \mathrm{C}_{22: 1}(4 \cdot 4 \%)$ and $\mathrm{C}_{18: 1}(3 \cdot 8 \%)$. The $\mathrm{G}+\mathrm{C}$ content of the genomic DNA is $49 \cdot 2$ mol\% (HPLC). Isolated from sandy-beach sediment and fluids at a coastal hot spring, Ibusuki, in Kagoshima Prefecture, Japan.

The type strain is $\mathrm{IBSK}^{\mathrm{T}} \quad\left(=\mathrm{JCM} \quad 12173^{\mathrm{T}}=\mathrm{ATCC}\right.$ BAA $-821^{\mathrm{T}}$ ).

\section{Acknowledgements}

We are grateful to Mr Takahiko Higasa, Graduate School of Agriculture, Kyoto University, Japan for the electron micrographs. This work was partially supported by a Grant-in-Aid for Science Research (no. 12460093) from the Ministry of Education, Culture, Sports, Science and Technology of Japan. Satoshi Nakagawa was supported by the Research Fellowship of the JSPS.

\section{References}

Allen, S. E., Grimshaw, H. M., Parkinson, J. A. \& Quarmby, C. (1974). Inorganic constituents: nitrogen. In Chemical Analysis of Ecological Materials, pp. 184-206. Edited by S. E. Allen. London: Blackwell Scientific Publications.

Balch, W. E., Fox, G. E., Magrum, L. J., Woese, C. R. \& Wolfe, R. S. (1979). Methanogens: reevaluation of a unique biological group. Microbiol Rev 43, 260-296. 
Baross, J. A. (1995). Isolation, growth and maintenance of hyperthermophiles. In Archaea: a Laboratory Manual. Thermophiles, pp. 15-23. Edited by F. T. Robb \& A. R. Place. Cold Springer Harbor, NY: Cold Spring Harbor Laboratory.

Deckert, G., Warren, P. V., Gaasterland, T. \& 13 other authors (1998). The complete genome of the hyperthermophilic bacterium Aquifex aeolicus. Nature 392, 353-358.

DeLong, E. F. (1992). Archaea in coastal marine environments. Proc Natl Acad Sci U S A 89, 5685-5689.

Eder, W. \& Huber, R. (2002). New isolates and physiological properties of the Aquificales and description of Thermocrinis albus sp. nov. Extremophiles 6, 309-318.

Gillis, M., Vandamme, P., De Vos, P., Swings, J. \& Kersters, K. (2001). Polyphasic taxonomy. In Bergey's Manual of Systematic Bacteriology, 2nd edn, vol. 1, pp. 43-48. Edited by D. R. Boone, R. W. Castenholz \& G. M. Garrity. New York: Springer.

Huber, R., Wilharm, T., Huber, D. \& 7 other authors (1992). Aquifex pyrophilus gen. nov., sp. nov., represents a novel group of marine hyperthermophilic hydrogen-oxidizing bacteria. Syst Appl Microbiol 15, 340-351.

Huber, R., Eder, W., Heldwein, S., Wanner, G., Huber, H., Rachel, R. \& Stetter, K. O. (1998). Thermocrinis ruber gen. nov., sp. nov., a pink-filament-forming hyperthermophilic bacterium isolated from Yellowstone National Park. Appl Environ Microbiol 64, 3576-3583.

Jahnke, L. L., Eder, W., Huber, R., Hope, J. M., Hinrichs, K.-U., Hayes, J. M., Des Marais, D. J., Cady, S. L. \& Summons, R. E. (2001). Signature lipids and stable carbon isotope analyses of Octopus Spring hyperthermophilic communities compared with those of Aquificales representatives. Appl Environ Microbiol 67, 5179-5189.

Jukes, T. H. \& Cantor, C. R. (1969). Evolution of protein molecules. In Mammalian Protein Metabolism, pp. 21-132. Edited by H. N. Munro. New York: Academic Press.

Kawasumi, T., Igarashi, Y., Kodama, T. \& Minoda, Y. (1984). Hydrogenobacter thermophilus gen. nov., sp. nov., an extremely thermophilic, aerobic, hydrogen-oxidizing bacterium. Int J Syst Bacteriol 34, 5-10.

Kristjansson, J. K., Ingason, A. \& Alfredsson, G. A. (1985). Isolation of thermophilic obligately autotrophic hydrogen-oxidizing bacteria, similar to Hydrogenobacter thermophilus, from Icelandic hot springs. Arch Microbiol 140, 321-325.

Kryukov, V. R., Savel'eva, N. D. \& Pusheva, M. A. (1984). Calderobacterium hydrogenophilum nov. gen., nov. sp., an extreme thermophilic hydrogen bacterium, and its hydrogenase activity. Mikrobiologiya 52, 781-788.

Lauerer, G., Kristjansson, J. K., Langworthy, T. A., König, H. \& Stetter, K. O. (1986). Methanothermus sociabilis sp. nov., a second species within the Methanothermaceae growing at $97^{\circ} \mathrm{C}$. Syst Appl Microbiol 8, 100-105.

L'Haridon, S., Cilia, V., Messner, P., Raguénès, G., Gambacorta, A., Sleytr, U. B., Prieur, D. \& Jeanthon, C. (1998). Desulfurobacterium thermolithotrophum gen. nov., sp. nov., a novel autotrophic, sulphurreducing bacterium isolated from a deep-sea hydrothermal vent. Int J Syst Bacteriol 48, 701-711.

Matsunaga, K. \& Nishimura, M. (1969). Determination of nitrate in sea water. Anal Chim Acta 43, 350-353.

Nakagawa, S., Takai, K., Horikoshi, K. \& Sako, Y. (2003a). Persephonella hydrogeniphila sp. nov., a novel thermophilic, hydrogen-oxidizing bacterium from a deep-sea hydrothermal vent chimney. Int J Syst Evol Microbiol 53, 863-869.
Nakagawa, S., Takai, K., Horikoshi, K. \& Sako, Y. (2003b). Aeropyrum camini sp. nov., a strictly aerobic, hyperthermophilic archaeon from a deep-sea hydrothermal vent chimney. Int J Syst Evol Microbiol 54, 329-335.

Porter, K. G. \& Feig, Y. S. (1980). The use of DAPI for identifying and counting microflora. Limnol Oceanogr 25, 943-948.

Reysenbach, A.-L. (2001). Family I. Aquificaceae fam. nov. In Bergey's Manual of Systematic Bacteriology, 2nd edn, vol. 1, p. 360. Edited by D. R. Boone, R. W. Castenholz \& G. M. Garrity. New York: Springer.

Saitou, N. \& Nei, M. (1987). The neighbor-joining method: a new method for reconstructing phylogenetic trees. Mol Biol Evol 4, $406-425$.

Sako, Y., Nomura, N., Uchida, A., Ishida, Y., Morii, H., Koga, Y., Hoaki, T. \& Maruyama, A. (1996). Aeropyrum pernix gen. nov., sp. nov., a novel aerobic hyperthermophilic archaeon growing at temperatures up to $100^{\circ} \mathrm{C}$. Int J Syst Bacteriol 46, 1070-1077.

Sako, Y., Nakagawa, S., Takai, K. \& Horikoshi, K. (2003). Marinithermus hydrothermalis gen. nov., sp. nov., a strictly aerobic, thermophilic bacterium from a deep-sea hydrothermal vent chimney. Int J Syst Evol Microbiol 53, 59-65.

Shima, S. \& Suzuki, K. I. (1993). Hydrogenobacter acidophilus sp. nov., a thermoacidophilic, aerobic, hydrogen-oxidizing bacterium requiring elemental sulfur for growth. Int J Syst Bacteriol 43, 703-708.

Skirnisdottir, S., Hreggvidsson, G. O., Holst, O. \& Kristjansson, J. K. (2001). A new ecological adaptation to high sulfide by a Hydrogenobacter sp. growing on sulfur compounds but not on hydrogen. Res Microbiol 156, 41-47.

Soga, T. \& Ross, G. A. (1999). Simultaneous determination of inorganic anions, organic acids, amino acids and carbohydrates by capillary electrophoresis. J Chromatogr A 837, 231-239.

Stetter, K. O. (1988). Archaeoglobus fulgidus gen. nov., sp. nov. a new taxon of extremely thermophilic Archaebacteria. Syst Appl Microbiol 10, 172-173.

Suzuki, M., Cui, Z. J., Ishii, M. \& Igarashi, Y. (2001). Nitrate respiratory metabolism in an obligately autotrophic hydrogenoxidizing bacterium, Hydrogenobacter thermophilus TK-6. Arch Microbiol 175, 75-78.

Swofford, D. L. (2000). PAUP*. Phylogenetic analysis using parsimony (and other methods), version 4. Sunderland, MA: Sinauer Associates.

Takai, K., Komatsu, T. \& Horikoshi, K. (2001). Hydrogenobacter subterraneus sp. nov., an extremely thermophilic, heterotrophic bacterium unable to grow on hydrogen gas, from deep subsurface geothermal water. Int J Syst Evol Microbiol 51, 1425-1435.

Takai, K., Hirayama, H., Sakihama, Y., Inagaki, F., Yamamoto, Y. \& Horikoshi, K. (2002). Isolation and metabolic characteristics of previously uncultured members of the order Aquificales in a subsurface gold mine. Appl Environ Microbiol 68, 3046-3054.

Takai, K., Nakagawa, S., Sako, Y. \& Horikoshi, K. (2003). Balnearium lithotrophicum gen. nov., sp. nov., a novel thermophilic, strictly anaerobic, hydrogen-oxidizing chemolithoautotroph isolated from a black smoker chimney in the Suiyo Seamount hydrothermal system. Int J Syst Evol Microbiol 53, 1947-1954.

Tamaoka, J. \& Komagata, K. (1984). Determination of DNA base composition by reverse-phase high-performance liquid chromatography. FEMS Microbiol Lett 25, 125-128.

Van Dover, C. L., Humphris, S. E., Fornari, D. \& 24 other authors (2001). Biogeography and ecological setting of Indian Ocean hydrothermal vents. Science 294, 818-823. 